\section{A incrível história da fraude dos embriões clonados e o que ela nos diz sobre ciência, tecnologia e mídia*}

The amazing story of the fraudulent cloned embryos and what it tells us about science, technology, and the media

Iara Maria de Almeida Souza

Professora do Departamento de Sociologia e dos Programas de Pós-graduação em Ciências Sociais/Universidade Federal da Bahia (UFBA)

Rua Padre Camilo Torrend, 145/204 40210-650 - Salvador - BA - Brasi imas@ufba.br

\section{Amanda Muniz Logeto Caitité \\ Mestranda do Programa de Pós-graduação em Ciências Sociais/UFBA \\ Av. Paulo VI, 658/02 \\ 41810-001- Salvador - BA - Brasil amanda.munizlc@gmail.com}

Recebido para publicação em agosto de 2008. Aprovado para publicação em julho de 2009.
SOUZA, Iara Maria de Almeida; CAITITÉ, Amanda Muniz Logeto. A incrível história da fraude dos embriões clonados e o que ela nos diz sobre ciência,tecnologia e mídia. História, Ciências, Saúde - Manguinhos, Rio de Janeiro, v.17, n.2, abr.-jun. 2010, p.471-493.

\section{Resumo}

Analisa, a partir de notícias em jornais brasileiros, o caso da fraude científica dos embriões clonados, cometida pelo cientista sul-coreano Hwang. A exposição da ciência pela mídia costuma destacar aspectos intelectuais, descobertas e promessas de aplicação. Nesse caso a ciência é mostrada em seu avesso, e desvela-se a trama de fios que ligam elementos de naturezas diferentes: governo coreano, pesquisadores, instrumentos, fundos para pesquisa, óvulos e fungos, revistas científicas, entre outros. Tais vínculos, que constituem a ciência na prática, só ganham visibilidade na mídia devido às tensões entre esses diferentes elementos e aos aspectos ilícitos presentes nesse caso em particular.

Palavras-chave: fraude científica; teoria do ator-rede; divulgação científica; Hwang.

\section{Abstract}

Based on news reports from Brazilian papers, the article examines the case of scientific fraud involving cloned embryos, committed by South Korean scientist Hwang. The media generally focus on the intellectual process of science, its discoveries, and the new possibilities it promises. In this case, however, science is shown the other way around, revealing a web that interweaves elements of a radically disparate nature, like the Korean government, researchers, tools, research funds, human eggs and funguses, scientific journals, among others. These ties are what make up science in practice, yet they only become visible in the media when there is tension between them and, in this case, when something illicit happens.

Keywords: scientific fraud; actornetwork theory; scientific dissemination; Hwang. 
lara Maria de Almeida Souza, Amanda Muniz Logeto Caitité

$\mathrm{H}^{3}$ á muito as células-tronco embrionárias (CTE) têm atraído a atenção da mídia. O grande interesse despertado por elas se deve ao potencial terapêutico que representam e à controversa questão ética que envolvem, que pode ser sucintamente resumida nos seguintes termos: devemos considerar eticamente aceitável a realização de pesquisas com embriões humanos? No Brasil, depois da disputada votação, no Congresso, e do julgamento, no Supremo Tribunal Federal, da ação de inconstitucionalidade contra a Lei de Biossegurança, foi aprovada a realização de pesquisas com embriões estocados em clínicas de fertilização e, com isso, foi posto um ponto final na controvérsia jurídica. A volta do tema aos jornais atualmente se dá pela eventual divulgação de algum resultado, sempre parcial, das pesquisas com células-tronco. E, caso os seus efeitos terapêuticos se mostrem pífios no futuro, é possível que elas caiam no esquecimento, pois a mídia não costuma noticiar os reveses científicos (Priest, 2001; Petersen, 2002). Mas há exceções, e uma delas diz respeito justamente a um golpe sofrido pelas pesquisas com células-tronco embrionárias (CTEs). É sobre esse episódio que refletiremos neste artigo.

Entre os tantos textos escritos sobre as pesquisas com células-tronco, chama a atenção aqueles que versam sobre a história do cientista coreano Woo Suk Hwang, que teria sido o primeiro a produzir embriões humanos clonados. Sua grande realização, entretanto, como mais tarde se descobriu, não passava de uma fraude. $\mathrm{O}$ artigo que ele publicara na revista Science, em 2005, no qual anunciava ter cultivado 11 linhagens de células-tronco derivadas de embriões humanos clonados, era baseado em dados falsificados. Ele efetivamente não clonou embriões humanos, e as colônias de células que apresentava provinham de embriões produzidos por fertilização in vitro. Um ano após ser publicado o artigo que anunciava a primeira tentativa exitosa de clonar um embrião humano para fins terapêuticos, revelouse que ele era forjado, e o fato foi amplamente alardeado na imprensa.

O impacto imediato do caso foi tamanho, que levou um colunista de ciência da Folha de S.Paulo a anunciar: "Este foi um ano trágico para a pesquisa em biotecnologia" (Células de decepção..., 24 dez. 2005). O ano era 2005, e a causa da tragédia fora a descoberta da fraude dos embriões humanos clonados. No início daquele mesmo ano, o tom do noticiário era bem outro: Hwang era denominado "pioneiro da clonagem terapêutica" e se havia tornado uma celebridade científica (Promessa na medicina..., 13 fev. 2004; Coreano que criou clones..., 18 jun. 2005). Quais eram as promessas trazidas pelas suas pesquisas? A reconstituição de qualquer tecido do nosso corpo a partir de células-tronco extraídas de embriões clonados da própria pessoa. Os novos órgãos e tecidos seriam feitos sob medida para cada doente, de tal modo que as possibilidades de rejeição nos transplantes seriam praticamente abolidas (Promessa na medicina..., 13 fev. 2004; Grupo que fez primeira cópia..., 20 maio 2005). Em linhas gerais, era assim que se descrevia, nos jornais, a clonagem terapêutica. A revelação da fraude teve como efeito um arrefecimento da expectativa com relação às terapias com CTE e a derrocada de um cientista admirado e considerado um herói por seus compatriotas.

A perplexidade advinda da descoberta da fraude gerou muitas interrogações sobre como ela fora urdida: como foi possível que dados fictícios viessem a público em um periódico de prestígio e, principalmente, quais teriam sido as causas de Hwang para executar o ardil. As perguntas geravam explicações baseadas ora na própria personalidade do cientista (suas 
motivações para tramar e executar o estratagema), ora nas condições que tornaram a fraude possível (relativas à ciência). Nosso interesse na questão, entretanto, se desloca para outro ponto. Não pretendemos esclarecer tais causas, mas abordar esse acontecimento extraordinário - uma grande fraude e sua divulgação - para que ele nos revele o modo ordinário de fazer ciência, que raramente tem lugar no noticiário: as atividades práticas dos cientistas, a organização do trabalho no laboratório, as redes que compõem a ciência, os diferentes interesses e tipos de atores (humanos e não humanos) presentes em sua produção. Usualmente o jornalismo, ao tratar da ciência, privilegia seus aspectos intelectuais, os conteúdos da pesquisa, as descobertas e promessas de aplicação (Petersen, 2002; Mulkay, 1997; Malone, Boyd, Bero, 2000), mas graças a Hwang e a sua fraude aquilo que em geral fica no lado avesso da divulgação científica, a trama de fios que liga a pesquisa a inúmeras outras instâncias, acabou por tornar-se visível para um público que, em geral, desconhece a ciência por esse ângulo. Certamente o episódio aqui retratado não produziu nenhum abalo significativo na confiança que o conhecimento científico goza entre os leigos; apenas permitiu-lhes entrever por um momento aquilo de que é feita a ciência - a relação entre instâncias heterogêneas.

Para mostrar como se dá a passagem das imagens da ciência como descoberta e aplicação para uma visão dela como resultado de ordenamentos, atividades práticas e uma série de alianças entre atores heterogêneos, analisamos as notícias publicadas em edições on line da Folha de S.Paulo, de O Globo e de O Estado de S.Paulo, que estão, de acordo com a Associação Nacional de Jornais (ANJ), entre os jornais de maior circulação no país. Coletamos as notícias sobre Hwang publicadas a partir de 2004 - ano em que foi divulgado, na Science, o artigo em que o cientista afirmava ter produzido o primeiro embrião humano clonado -, até o início de 2006, quando a dupla fraude foi confirmada. Como resultado dessa coleta, obtivemos 427 textos em que havia alguma referência a Hwang e/ou ao caso dos embriões clonados. Desses, eliminamos pequenas notas informativas, editoriais e matérias em que a citação era meramente casual, o que reduziu para 145 o número de artigos. Como os jornais brasileiros tendiam a replicar notícias distribuídas pelas agências internacionais, não era raro coletarmos textos quase idênticos publicados, em um mesmo dia, em diferentes jornais. Por conta disso, reduzimos o número de matérias a serem examinadas a 40, das quais fizemos uma análise de conteúdo centrada nos aspectos priorizados pela imprensa: inicialmente a descoberta de Hwang e suas possíveis aplicações e, posteriormente, a questão ética relativa à pesquisa, o questionamento dos seus resultados, a descoberta da fraude, como esta se deu e quais as suas causas.

A análise dessas matérias, por um lado, permitiu reconstituir a história de Hwang e seus desdobramentos e, por outro, forneceu indicações dos aspectos da ciência que são valorizados na cobertura jornalística. Os artigos publicados na Science em 2004 e 2005, por Hwang e outros autores, também foram objeto de nossa atenção. A leitura desses textos, entretanto, não visava estabelecer uma comparação entre o artigo publicado no periódico científico e a sua tradução para leigos na imprensa, mas sim nos dar mais subsídios para a compreensão do caso. 


\section{Como abordar o caso Hwang?}

A descoberta de uma fraude quase sempre suscita questões acerca de suas causas. No jornalismo, tende-se a buscar, nos traços da personalidade do cientista, aquilo que o leva à fraude (desejo desmedido de glória, interesses escusos etc.), embora em alguns momentos, no caso de Hwang, aspectos institucionais da ciência tenham sido levados em conta (Kruvand, Hwang, 2007). Em publicações científicas, o debate sobre o caso de Hwang enfocou o modo como a fraude foi urdida, assim como se voltou para a proposição de mecanismos institucionais de controle capazes de detectar as tentativas de burlar os instrumentos de avaliação da ciência (Gotweis, Triendl, 2006; Franzen, Rödder, Weingart, 2007; Bains, 2006; Vara, 2006; Benítez-Bribiesca, Modiano-Esquenazi, 2006; Benos et al., 2007; Schachman, 2006).

Na sociologia e na antropologia da ciência, a fraude científica não é tópico muito explorado. A bibliografia é relativamente escassa, e usualmente o tema parece demandar um enquadramento normativo, ou seja, a fraude é tratada como um desvio com relação ao padrão normativo que deve orientar a conduta dos cientistas (Merton, 1985). Tratar a questão da fraude como uma abordagem sociológica requer que a atenção se volte para as dimensões sistêmicas e sociais do desvio, ou seja, implica atentar para aquilo que, no funcionamento da ciência, conduz à transgressão dos padrões normativos ou a favorece. As causas apontadas são: política do publish or perrish, que impele os cientistas a produzir ininterruptamente; pressão para alcançar resultados que garantam financiamentos; o advento da big science e a mudança na organização do trabalho, que dilui a responsabilidade dos cientistas com relação à pesquisa; inexistência de uma regulação científica rigorosa; interferência da indústria de biotecnologia (Fox, 1990; Shapiro, Wenger, Shapiro, 1994; Lytton, 1996).

As questões postas pelo jornalismo, pelas publicações científicas e pela sociologia da ciência se aproximam em termos de estratégia de enfoque: todas privilegiam uma abordagem causal embora se diferenciem quanto ao escopo e ao tipo de explicação que é encontrada. Neste artigo, ao abordarmos a fraude cometida por Hwang e sua divulgação, não procuraremos estabelecer quais as suas causas. Inspiradas na etnometodologia, trataremos a fraude como um desses momentos de quebra de expectativas, nos quais se revela um vasto campo de pressupostos que só ganha visibilidade justamente com tal ruptura. (Garfinkel, 1967).

Além da etnometodologia, as etnografias de laboratório e trabalhos que utilizam a teoria do ator-rede foram bastante úteis na nossa abordagem ao tema. Uma questão comum a esses estudos diz respeito à concepção da investigação científica como um conjunto de atividades através do qual o mundo é construído, e não simplesmente descrito como algo dado. Além disso, tais estudos fazem referência às propriedades contextuais e contingentes desse processo de produção (Knorr-Cetina, 1983, 1999; Pickering, 1995; Lynch, 1993). Dizer que fatos científicos são construídos não conduz a um total relativismo; significa, antes, que sua fabricação envolve a mobilização de entidades heterogêneas em uma associação que não é dada, é incerta e pode falhar (Latour, 2005) - e efetivamente falhou, no caso de Hwang.

Há ainda um ponto relativo aos estudos sobre prática científica que merece ser mencionado e que diz respeito às relações entre o laboratório e o que está além dele. Os fatos 
objetivos produzidos pela ciência não dependem apenas da realização de procedimentos técnicos que mobilizam entidades no mundo e da construção de teorias que os explicam, mas também da articulação de uma rede de sustentação que envolve política, representação pública, legislação, divulgação, alianças com indústrias e governo etc. Assim, não há como determinar um limite claro entre os domínios interno e externo à ciência (Stengers, 2002; Knorrr-Cetina, 1999; Latour, 2000; Law, 1989). Os fatos produzidos nas bancadas de laboratório ganham mais realidade ao ser traduzidos pelas outras instâncias que se aliam para confirmar sua existência. Nesse sentido, quando se traduz o conhecimento produzido no laboratório em notícias sobre descobertas científicas, o que se faz é articular e fortalecer a existência de fatos, dar-lhes a chance de ganhar vida em outros tempos e lugares (Horst, 2005; Neresini, 2000; Latour, 2000).

Se a mídia contribui para consolidar e estabilizar a existência de um fato científico no mundo fora do laboratório, podemos nos perguntar de que modo a divulgação de notícia contribui para firmar uma realização científica. Entre os vários procedimentos envolvidos na estabilização de um fato, há dois aspectos para os quais chamamos a atenção. O primeiro é que a divulgação de ciência tende a eliminar a incerteza, pois usualmente, quando uma descoberta é publicada, as dúvidas e controvérsias científicas sobre o fato não são divulgadas (Kua, Redeer, Grossel, 2004). Já o segundo é que o procedimento utilizado na produção dos fatos é simplificado - conforme o sentido atribuído por Law (1989) a esse termo. Para ele, simplificação é o processo pelo qual as heterogêneas e complexas redes de interação que sustentam a ciência são veladas de tal modo que a heterogeneidade desaparece e surge, em seu lugar, uma unidade: a rede é substituída por uma ação específica e pelo autor, aparentemente único, dessa ação. A mídia simplifica, pois atribui uma realização a um ator singular. No caso de Hwang, antes da descoberta da farsa, ele era o autor único de uma grande realização: a produção de linhagens de células-tronco de embriões humanos clonados. Uma vez que a fraude é exposta, o ator único desaparece, outros agentes entram em cena e a rede começa a aparecer em sua complexidade. Na história que tratamos aqui, a certa altura o tecido de sustentação da versão da realidade proposta por Hwang começou a esgarçar e se rompeu. Observemos então, ao menos fugazmente, o que se torna visível nesse caso.

\section{A primeira face de Hwang: o Cientista Supremo}

Hwang era veterinário, professor e pesquisador da Universidade Nacional de Seul (UNS), e ganhara notoriedade por seus experimentos com clonagem de mamíferos. A grande proeza, que o alçou à condição de celebridade científica, foi o anúncio, publicado na Science em 2004, da produção de uma linhagem de células-tronco derivada de embrião humano clonado. Para uma melhor compreensão do que isso representava em termos de avanço científico, apresentamos brevemente os procedimentos utilizados pela equipe de Hwang e as dificuldades que enfrentou.

Primeiro Hwang precisou clonar embriões humanos, um feito inédito. Ele recorreu à mesma técnica utilizada anteriormente para clonagem de outros mamíferos, como Dolly: transferiu o núcleo de uma célula somática para um óvulo enucleado e em seguida o óvulo 
- com material genético do doador - foi ativado para que se iniciasse o processo de reprodução. Hwang adaptou o protocolo usado para clonagem de outros animais e conseguiu obter, a partir de 242 óvulos, trinta embriões, que foram mantidos vivos até atingir o estágio blastócito (fase alcançada após cinco a sete dias de fecundação). Tendo sucesso nessa etapa, o próximo procedimento envolvia um trabalho extremamente delicado: a extração de células-tronco da parte interna da esfera oca que o embrião havia se tornado. Vinte dessas células foram obtidas e cultivadas, o que resultou na produção de uma linhagem de células-tronco, ou seja, células que se multiplicam durante várias gerações mantendo as mesmas características (Hwang et al., 2004). Embora o artigo em que o pesquisador apresentava esse feito não excluísse a possibilidade de ocorrência de uma origem partenogênica da linhagem de células-tronco, as evidências apresentadas indicavam fortemente que a linhagem produzida era de fato resultado de clonagem. As tabelas e imagens mostradas, bem como a indicação dos testes realizados, funcionavam no texto como o 'referente' que sustentava a afirmação de que a clonagem havia sido bem-sucedida (Hwang et al., 2004).

A superação de tantas dificuldades na clonagem e produção de CTE foi considerada uma proeza extraordinária, pois o desenvolvimento dessa técnica significava um avanço em direção à clonagem terapêutica, que visa à produção de células-tronco pluripotentes para pesquisa, regeneração e transplante sem risco de rejeição (Promessa na medicina..., 13 fev. 2004).

Em 2005 Hwang voltou a surpreender o mundo científico ao anunciar outro feito sem precedentes (Coreia do Sul cria células-tronco..., 9 maio 2005). Em outro artigo publicado na Science, afirmava que haviam sido produzidas 11 linhagens derivadas de embriões clonados de pacientes portadores de doenças graves. Dessa vez bastaram 185 óvulos, extraídos de 18 mulheres, para a produção de 31 blastócitos, dos quais foram originadas e cultivadas 11 linhagens de CTEs. Assim como o artigo anterior, o novo reproduzia imagens e tabelas que evidenciariam a existência de equivalência entre o DNA dos doadores e o material genético das linhagens de células-tronco. O progresso alcançado representou uma superação notável, pois nesse artigo se dirimia qualquer dúvida de que as células poderiam ter-se multiplicado por partenogênese. Além disso, o protocolo utilizado, modificado em vários aspectos, teria ampliado a taxa de sucesso na clonagem e promovido um incremento na produção de blastócitos, no isolamento de CTEs e no cultivo de linhagens. E mais: dessa vez o meio de cultura utilizara exclusivamente insumos humanos, o que poderia reduzir o tempo entre a pesquisa de bancada e o ensaio clínico (Hwang et al., 2005).

Por conta desses resultados excepcionalmente promissores, no início de 2005 publicouse uma profusão de notícias sobre a técnica de clonagem desenvolvida por Hwang. É bem verdade que, com frequência, ele aparecia ao lado de seu colaborador americano Gerard Schatten, renomado pesquisador da área de células-tronco (Grupo produz linhagens..., 19 maio 2005). Quase sempre Hwang estava em reuniões e congressos internacionais e raramente estava em seu laboratório. O próprio anúncio de sua descoberta foi feito nos EUA. Hwang personificava, então, a imagem do cientista empresário descrito por Law (1989), aquele que representa a personalidade exterior do laboratório, seu porta-voz, mandatário das células e dos pesquisadores que as estudam. Justamente por isso, seu campo de ação 
não se restringe ao laboratório, e sua atuação é bem mais ampla. Ele se relaciona com colegas de outras instituições, editores de revistas, políticos e financiadores de pesquisas. Para o funcionamento do laboratório é essencial que ele consiga congregar e obter apoio de todas essas entidades.

Apesar de falar do mundo e para o mundo, Hwang é um cientista sul-coreano, seu laboratório se situa na Universidade Nacional de Seul, e isso importa para a sua pesquisa. Por um lado, as severas restrições legais à realização de experimentos com embriões em países líderes na produção científica, em especial os EUA, permitiram aos países que possuem uma legislação mais liberal com relação a tais pesquisas, como a Coreia do Sul, passar à posição de vanguarda no desenvolvimento de estudos com CTE. "O número um na clonagem humana" - este era o aposto com o qual Hwang era frequentemente citado nos jornais, o que aponta para o reconhecimento do pioneirismo do seu trabalho. Por outro lado, essas pesquisas eram consideradas estratégicas para o seu país e para toda a ciência coreana (Sul-coreanos propõem..., 25 jun. 2005). Por isso Hwang recebeu o título de Cientista Supremo, distinção que envolvia, além de honra e prestígio, a concessão de financiamento para o seu laboratório e para a criação do banco mundial de CTE, que distribuiria linhagens para cientistas de todos os países (Coreia do Sul cria banco..., 20 out. 2005).

A partir de 2004 o trabalho de Hwang recebeu ampla divulgação na imprensa. A ênfase, como acontece no noticiário sobre ciência, era posta nos conteúdos da pesquisa e em suas possíveis aplicações (Mulkay, 1997; Malone, Boyd, Bero, 2000). O padrão usual das matérias envolvia uma explicação do que eram as células-tronco, qual o seu uso potencial para o tratamento de doenças, o que eram CTEs clonadas e suas vantagens, quem era Hwang e o que ele havia feito (Promessa na medicina..., 13 fev. 2004; Grupo que fez primeira cópia..., 20 maio 2005). Possíveis discordâncias teóricas e/ou metodológicas não eram mencionadas; na imprensa as CTEs eram um fato. Havia a controvérsia ética, mas era tratada como uma questão exterior à ciência, relativa aos valores que regulam de fora as atividades dos cientistas.

No processo de simplificação operado pelo jornalismo, as descobertas científicas costumam aparecer como fatos concretos, resultantes de testes experimentais e elaborações teóricas. A forma pela qual elas são produzidas se torna velada: as múltiplas interações que envolvem os pesquisadores, os artefatos presentes nos laboratórios, seus financiadores e seus públicos potenciais não são tópicos relevantes no noticiário (Mulkay, 1997; Petersen, 2002, Malone, Boyd, Bero, 2000; Priest, 2001). Contudo, como aponta Law (2005), qualquer estabilização é precária. Não há garantias de que todos os componentes de uma rede funcionarão conforme o previsto, e é justamente por conta das falhas que ela se torna visível. É isso que se dá no caso de Hwang: à medida que avançam as investigações da fraude, desvela-se uma complexa rede de transações, algumas das quais condenáveis ética e legalmente.

\section{A outra face de Hwang: 0 cientista falaz}

Como dissemos, a rede em que se sustenta a tecnologia para a produção de linhagens de células-tronco a partir de embriões humanos clonados se explicitou quando passaram a ser questionadas a legitimidade do processo de pesquisas e a veracidade dos seus achados. 
Vejamos como isso aconteceu. Em novembro de 2005, começaram a surgir, na imprensa, matérias que questionavam os procedimentos éticos utilizados por Hwang na obtenção de óvulos para seus experimentos. Ao contrário do que se afirmara nos artigos, os óvulos não foram obtidos voluntariamente, mas sim comprados. Além disso, algumas pesquisadoras do laboratório teriam sido forçadas a fazer doações (Americano vê problema..., 14 nov. 2005; Sul-coreano admite..., 21 nov. 2005; Pioneiro da clonagem admite..., 24 nov. 2005).

Esse é dos primeiros elos da rede a se explicitar. Nas notícias publicadas anteriormente sobre o trabalho do cientista, o modo como os óvulos foram obtidos era desconsiderado; mencionavam-se apenas os 11 doentes que haviam doado material genético para a produção de clones (Grupo produz linhagens..., 19 maio 2005). O óvulo, que não implicava fornecimento de material genético, não era avaliado como parte importante do processo, mas sim mero intermediário, algo que simplesmente leva adiante aquilo que recebeu sem produzir qualquer alteração significativa. Seu papel como mediador, ou seja, como algo que imprime ao processo alguma diferença (Latour, 2005), passou a ser reconhecido quando foram desvelados os mecanismos de sua obtenção.

As primeiras acusações foram divulgadas por um canal de tevê, a $\mathrm{MBC}$, que teria obtido a informação de uma fonte anônima ligada ao laboratório de Hwang - depois se soube que o informante era um estudante de mestrado, que denunciou não só as falhas éticas como também problemas relativos à manipulação de dados, embora este último aspecto só se tenha tornado notícia posteriormente (TV sul-coreana deve questionar..., 2 dez. 2005). Uma emissora concorrente, mais favorável ao cientista, por sua vez, denunciou os métodos pouco éticos utilizados pela MBC para forçar um membro da equipe de pesquisa a falar dos deslizes cometidos na realização do experimento. A MBC foi forçada a se desculpar (TV coreana admite falha..., 5 nov. 2005). Assim, Hwang, com apoio de parte da imprensa, foi temporariamente bem-sucedido em silenciar os desacordos. Com a controvérsia jornalística, a opinião pública foi mobilizada e tendeu a apoiar o cientista, considerado herói nacional. Mulheres fizeram passeata e prometeram doar seus óvulos a Hwang, para que ele pudesse continuar suas pesquisas sem transtornos. O representante do Hospital MizMedi assumiu a culpa pela compra dos óvulos e eximiu Hwang de qualquer responsabilidade pelo ato (Sul-coreanas prometem doar..., 6 dez. 2005).

O episódio - primeiro ato no drama da derrocada de Hwang - nos permite tratar da relação da ciência com o público leigo. Como se dá a apropriação, por parte de leigos, daquilo que é produzido no âmbito das tecnociências? Um dos modos privilegiados de a ciência se comunicar com os não especialistas envolve justamente a mediação da imprensa, por meio dos textos que divulga. Assim, a forma como as descobertas são expostas na mídia pode ter múltiplas consequências, desde a recusa a uma técnica à predisposição para se submeter a testes, ou a mobilização para a aprovação de uma lei. No caso de Hwang, a imagem que ele gozava nos meios de comunicação era a de trabalhador disciplinado e interessado na produção de um bem inestimável: o tratamento de doenças até então incuráveis (Perfil..., 24 dez. 2005). Por isso, quando começou a polêmica em torno da compra de óvulos, as coreanas assumiram um papel ativo no apoio ao cientista. O que é exposto nos jornais, portanto, representa um dos nós da rede da ciência, aquele que a conecta 
à opinião pública, essa entidade uma tanto vaga que, em certos contextos, pode adquirir contornos mais precisos e adotar posição ativa na sustentação da pesquisa.

Seguindo o fio da história, novos atores ingressam na trama: as empresas de biotecnologia. Sua entrada em cena se deu quando a controvérsia ética veio à tona e, ligada a ela, noticiou-se a queda no preço das ações das empresas de biotecnologia (Ambição de publicar..., 29 dez. 2005; Ex-admiradores de sul-coreano..., 12 jan. 2006). Na maior parte das vezes, em notícias sobre biotecnologia não se mencionam os interesses financeiros que guiam as pesquisas, nem como se dará o acesso aos possíveis benefícios resultantes das descobertas científicas (Mulkay, 1997; Malone, Boyd, Bero, 2000; Priest, 2001). Os textos anteriores sobre CTEs não eram exceção: o potencial terapêutico era o foco mais frequente e nenhuma alusão se fazia ao modo como se daria o acesso aos tratamentos, nem havia referência ao papel da indústria nesse processo. No entanto, os interesses das empresas de biotecnologia nas pesquisas foram evidenciados quando a crescente polêmica em torno do trabalho do cientista provocou impacto negativo no preço das ações. Além disso, o vínculo entre indústria e ciência foi claramente explicitado após a confirmação da fraude, quando cientistas foram instados a dar explicações para a ação de Hwang. Na opinião de um deles, o artigo publicado por Hwang em 2004 não apontava para o uso da pesquisa por parte da indústria, e por isso o pesquisador sul-coreano fora pressionado a publicar algo que demonstrasse claramente as potencialidades da clonagem terapêutica, a fim de atrair investimentos de empresas de biotecnologia (Ambição de publicar, 29 dez. 2005; Exadmiradores de sul-coreano..., 12 jan. 2006).

Voltemos ao desenrolar da história de Hwang. Ele saíra momentaneamente vitorioso do confronto inicial (Americano vê problema..., 14 nov. 2005; TV coreana admite falha..., 5 nov. 2005), mas isso não foi suficiente para fazer cessar a polêmica. O cientista sofreu em seguida mais um forte ataque: em um programa na $\mathrm{MBC}$, um de seus colaboradores - que estava pesquisando com Schatten nos Estados Unidos - admitiu que os problemas não se limitavam à utilização de métodos condenáveis na aquisição de óvulos. Teria havido também falhas na pesquisa. Segundo o informante, Hwang não conseguira produzir as 11 linhagens conforme afirmava, mas apenas duas delas, e havia dúvidas se foram derivadas de embriões clonados. O colaborador revelou ainda que as imagens apresentadas no artigo da Science foram replicadas e manipuladas para que parecessem ser fotos das várias linhagens. Diante das denúncias, Hwang confessou a ocorrência de erros de edição: algumas fotos haviam sido duplicadas no artigo publicado, mas a revista fora advertida a esse respeito. A editora da Science, ouvida pelo jornal, afirmou que tais erros não afetavam a validade da pesquisa (Cientista coreano aponta erro..., 7 dez. 2005).

No momento em que um membro da equipe vem a público fazer acusações e revelar falhas na pesquisa, Hwang já não estava mais situado na posição de único e legítimo porta-voz, aquele que fala em uníssono pelo grupo. O consenso se rompera, e tensões e disputas presentes no laboratório emergiram e se tornaram públicas. A partir de então as acusações se multiplicaram: falhas éticas, manipulação de dados e proveito financeiro indevido. Hwang saiu brevemente de cena, com a saúde afetada pela 'polêmica ética', e durante sua ausência a controvérsia sobre a validade dos dados ganhou o primeiro plano (Fadiga leva cientista..., 7 dez. 2005). 
Um fato decisivo para a sorte de Hwang foi a publicação, na internet, de um texto anônimo com sérias críticas ao artigo publicado na Science (depois se soube que o autor era um jovem cientista coreano). O texto não se apoiava em depoimentos de colaboradores ou ex-colaboradores, mas fornecia detalhes técnicos que funcionavam como testemunhas contra Hwang e faziam ampliar a desconfiança com relação ao seu trabalho (Grupo de 30 pesquisadores..., 12 dez. 2005). A crítica incidia basicamente sobre as provas genéticas apresentadas pelo cientista. A questão diz respeito ao seguinte: uma vez que as colônias de células podem ser contaminadas por outras culturas de células, a comprovação de que uma linhagem é idêntica, do ponto de vista genético, àquela que lhe deu origem exige a realização de testes de DNA. Usualmente essas análises geram imagens que não são idênticas entre si, mostrando diferenças nos dados do DNA ou no chamado ruído de fundo, mesmo nos casos em que a clonagem se efetivou. No artigo publicado por Hwang, várias imagens não mostravam diferenças entre si, o que levava o autor da crítica a suspeitar que não se tratava de células diferentes, mas sim de uma mesma célula em imagens duplicadas. Isso poderia ser um erro de edição - alegação inicial de Hwang -, ou significaria que, na verdade, não havia clone algum.

Essa crítica é contundente porque as imagens inseridas no texto científico costumam ser consideradas elementos que avalizam a objetividade de um fato. Por isso, segundo Daston (2005), qualquer fotografia ou registro produzido por instrumento, por mais impreciso que seja, é considerado superior a um desenho bem feito, pois este traria a marca da subjetividade, que é supostamente eliminada quando se apela para a vigilância e o registro feito por não humanos. Logo, o que aconteceu foi uma drástica perda de confiança na objetividade dos dados apresentados por Hwang em seu artigo.

Entretanto, o texto que apontava as fragilidades do artigo publicado na Science só veio a público quando a imagem de seu autor estava enfraquecida. Por que se esperou pelas primeiras denúncias para apontar um erro que já havia sido percebido? Um dos poucos trabalhos a que podemos nos reportar para compreender a delação pública da fraude é o artigo de Hopwood (2006), sobre as acusações lançadas contra Haeckel, ilustrador de embriologia denunciado por falsificar figuras e exagerar as semelhanças entre mamíferos, com o intuito de favorecer a teoria da evolução de Darwin. Hopwood pretende entender como a fraude se tornou uma questão, pois embora a falsificação fosse conhecida, "os leitores competentes não foram unânimes em ver imediatamente qualquer problema com isso" (p.35). ${ }^{1}$ Segundo ele, a adulteração só se converteu em tópico de disputa quando alguns especialistas decidiram tornar motivo de controvérsia o que sabiam havia muito tempo, ou seja, a fraude era conhecida, mas só foi denunciada em circunstâncias favoráveis à contestação pública.

Há também casos em que, embora a manipulação de dados seja reconhecida, ela não chega a ser objeto de denúncia ou controvérsia. Geneticistas contemporâneos afirmam que Mendel provavelmente manipulou dados estatísticos. É também de conhecimento público que Robert Milikan, prêmio Nobel de física, excluiu de seu trabalho dados que não se ajustavam a suas hipóteses. Segundo Franzen, Rödder e Weingart (2007), em ambos os casos não se instaurou uma denúncia pública porque as teorias que eles advogavam permaneceram válidas, a despeito da manipulação dos dados. Se tal argumento está correto, 
não basta a violação de um padrão normativo da ciência para que uma fraude se torne publicamente relevante.

A inexistência de uma relação direta entre o reconhecimento da manipulação de dados e a denúncia/sanção aponta, portanto, para as limitações do modelo normativo na explicação da fraude, pois mostra que os atores não são seguidores cegos das normas nem 'idiotas avaliativos', antes ajustando flexivelmente as normas e regras às situações de ação (Lynch, Woolgar, 1988; Lynch, 2002; Shorett, Rabinov, 2003; Delgado, Vallverdú, 2007). Aqui reencontramos a noção de escolhas contextuais e contingentes das quais falam os estudos de prática científica e as etnografias de laboratório (Lynch, 1993, 2002; KnorrCetina, 1999, 1983; Garfinkel, 1967). Se é assim, em vez de centrar a análise no caráter normativo da ciência, deveríamos atentar para os modos de interpretação e produção de sentidos que fazem com que certas ações - como a decisão de tornar pública uma fraude pareçam plausíveis em determinadas circunstâncias e não em outras. Seguindo essa indicação, podemos pensar que aqueles que sabiam ou ao menos suspeitavam da fraude de Hwang não haviam encontrado, até então, uma situação favorável para a refutação do seu trabalho e a denúncia de fraude.

Isso nos deixa, entretanto, com uma indagação. Os aliados de Hwang talvez não encontrassem motivo para expor publicamente os problemas com a pesquisa. Mas o que dizer de seus concorrentes? Por que não reagiram prontamente, apontando os erros do artigo que, por dizerem respeito às imagens, eram tão visíveis? O campo científico não é, como argumenta Bourdieu (1994), lócus de luta por prestígio e reconhecimento, em que produtores tendem a ter como possíveis clientes justamente os seus concorrentes, que são os menos inclinados a reconhecer seus produtos sem discussão ou exame?

Artigos indicam que, na atualidade, a maioria das denúncias de fraude depende da delação de um insider (Franzen, Rödder, Weingart, 2007; Gotweis, Treindl, 2006; Latour, 2000) e não de concorrentes que, ao tentar repetir um experimento, se dão conta de que ele não é replicável. O fato de que um experimento não possa ser reproduzido em outro laboratório não indica necessariamente falseamento de dados, já que a replicação exigiria que os dois laboratórios tivessem as mesmas condições experimentais, o que raramente se dá (Franzen, Rödder, Weingart, 2007; Gotweis, Treindl, 2006). O argumento da não replicabilidade não é suficiente, entretanto, para esclarecer por que não foram apontados os problemas relativos às imagens no artigo de Hwang antes que houvesse a denúncia. Gilbert e Maulkay (1982) e Traweek (1988) talvez possam nos dar algumas pistas para entender por que isso não foi feito de imediato. De acordo com esses autores, erros, inconsistências e impropriedades (não necessariamente fraudes) que cientistas encontram nos trabalhos de seus pares só são abordados, em geral, em contextos informais. Para explicar por que falhas e enganos são mantidos na informalidade, Traweek (1988) arrisca a seguinte hipótese: ingressar e participar das redes de falatório representa o estágio conclusivo do treinamento dos pesquisadores. A fofoca cumpriria, portanto, o papel de reproduzir a cultura dos cientistas. Os textos que constam da literatura formal cumprem outras funções: representam o consenso, distribuem créditos e débitos. Assim, manter comentários depreciativos na informalidade não traz ônus para o 'fofoqueiro' e reforça o seu senso de pertencimento à comunidade de cientistas. 
No caso de Hwang, não podemos saber o que de fato aconteceu. Talvez pesquisadores atentos aos erros do artigo tenham expressado sua desconfiança apenas para um círculo íntimo. Quiçá ninguém percebeu as inconsistências nas imagens, pois pesquisadores, ao julgar os pares e suas publicações, pressupõem a confiabilidade dos testes, dos métodos, além de levar em conta os créditos do próprio cientista (Latour, 1999). O artigo parecia fazer sentido. Hwang usou testes apropriados e gozava, entre seus pares, da fama de ser um cientista excepcionalmente habilidoso (Fox, 2008). É provável, portanto, que os cientistas tenham negligenciado as imagens por acreditar na autenticidade do artigo. A despeito da escassez de evidências para afirmar precisamente o que criou, no caso de Hwang, um ambiente favorável a denúncias, o fato de as primeiras contestações terem emergido de seu próprio laboratório nos revela suas crescentes dificuldades para manter a sua união com os aliados, e disputas que eram veladas acabaram por se tornar audíveis para um público mais amplo.

O resultado, em especial decorrente da publicação do texto veiculado pela internet, foi a constituição de uma comissão independente para fazer uma investigação minuciosa dos trabalhos de Hwang. Sua criação foi exigência de pesquisadores ligados à Universidade Nacional de Seul (Pioneiro na clonagem acusado..., 16 dez. 2005; Universidade sul-coreana avaliará..., 20 dez. 2005), que se diziam preocupados com os danos de escândalo à credibilidade da ciência sul-coreana. Se antes as pesquisas de Hwang eram parte fundamental da estratégia de crescimento científico do país, seu descrédito ameaçava contaminar as demais áreas. E a editora da Science, que antes defendera Hwang, não mais se mostrou tão segura com relação ao artigo. Pediu explicações ao autor, submeteu os originais a um reexame e por fim, quando se constatou a fraude, retirou o artigo da edição on line da revista.

Outro efeito da suspeita - e posterior confirmação - da fraude foi a explicitação do modo como se dá a revisão por pares, adotada pelas revistas científicas que gozam de legitimidade e prestígio junto a leigos e informados. Critérios rigorosos para a aceitação de um artigo são um dos pressupostos de credibilidade desses periódicos. Por isso, quando um jornal voltado para leigos noticia qualquer 'descoberta científica', publicada anteriormente em revistas como Science ou Nature, tal fato, por si só, confere credibilidade aos resultados apresentados (Mulkay, 1997; Petersen, 2002).

Quando começaram a se somar evidências de que houve um problema com os dados divulgados pela Science, a revista foi solicitada a responder à questão: como foi possível publicar uma fraude? (Como a Science publicou..., 2 jan. 2006). E foi precisamente nesse momento que se explicitou o processo de avaliação por pares. A editora esclareceu que os revisores não verificam in loco as pesquisas; cabem a eles apenas buscar inconsistências nos artigos. O sistema, portanto, se assenta em confiança, na crença na boa-fé dos cientistas, pois se supõe que os dados da pesquisa sejam autênticos e não forjados. Esse argumento é reiterado em artigos que discutiram o peer review após o escândalo Hwang (Franzen, Rödder, Weingart, 2007; Benos et al., 2007; Vara, 2006). Nesse caso, os revisores admitiram não ter atentado cuidadosamente para as imagens por causa de seu formato reduzido (BenítezBribiesca, Modiano-Esquenazi, 2006). Motivados pelo escândalo, comentadores sugerem a implementação de um sistema de salvaguardas para as publicações, mas admitem que o sistema não pode funcionar sem ter como base a confiança (Gottweiss, Triendl, 2006; Benos et al., 2007). 
Com efeito, o sistema de revisão por pares, a despeito das eventuais críticas a que é submetido, goza de grande confiança e é considerado o método por excelência de avaliação da ciência e seu principal mecanismo de autorregulação. Ele está fundamentado na ideia de que, para que um produto ingresse em domínio público - em uma publicação científica, por exemplo -, seu mérito deve ser reconhecido por 'iguais', ou seja, por aqueles que possuem a qualificação necessária para julgar a pertinência e veracidade do que é submetido à avaliação (Leibel, 1991; Davyt, Velho, 2000). A prática, portanto, constitui um dos mecanismos fundamentais da construção de fatos científicos, pois valida e autentica o conhecimento e legitima o pesquisador ao lhe conferir autoridade e prestígio. Mas, como mostram Davyt e Velho (2000), estudos em sociologia da ciência apontam para a impossibilidade de que, na prática, os avaliadores consigam separar julgamentos sobre assertivas lógicas de considerações que dizem respeito a situações, interações com diferentes atores, relevância extracientífica do tema etc. Não há como erradicar a relação com o contexto. Tal fato é do conhecimento dos próprios cientistas, mas só passa a ser considerado relevante em situações de controvérsia e dissenso (Lynch, 1993). Foi o que se deu no caso de Hwang: o sistema só veio a ser explicitado e discutido, quando se instalou uma situação de crise ainda que temporária - que pôs em questão o seu modo de funcionamento.

Ainda há outro aspecto relacionado à publicação, que chama a atenção: a questão da autoria. Estabelecer uma estratégia de publicação é crucial para consolidação da carreira de qualquer pesquisador, portanto quanto maior o número de publicações em periódicos de prestígio, mais estabelecido e competitivo será o cientista e seu laboratório (Latour, 2000). A necessidade permanente de manter um alto nível de publicações, consequentemente, dá margem a uma série de acordos em torno da autoria. O artigo publicado por Hwang, por exemplo, é assinado por 25 autores. É provável que nem todos tenham contribuído direta e efetivamente na pesquisa. Entre os autores encontramos, por exemplo, uma assessora da Presidência da Coreia, que mediava a relação entre Hwang e o governo. Embora fosse pesquisadora, sua área de atuação não era a das CTEs, e certamente sua autoria no artigo deve-se ao papel importante que desempenhou na obtenção de fundos para o laboratório (Fraude na clonagem..., 25 dez. 2005). Schatten, o colaborador americano da pesquisa, era também um dos autores do artigo e aparentemente possuía laços estreitos com o laboratório de Hwang (Como a ciência publicou..., 2 jan. 2006; Cientistas sul-coreanos clonam..., 3 ago. 2005; Animal ajudará estudo..., 4 ago. 2005). Entretanto, ele foi o primeiro a solicitar a retirada de sua autoria no artigo, sob a alegação de motivos éticos. Segundo seu depoimento, um pesquisador da equipe lhe revelara que alguns casos teriam sido inventados, o que o levou a um reexame dos dados apresentados no artigo. A avaliação criteriosa dos dados só foi feita, portanto, após a denúncia de fraude (Americano vê problema..., 14 nov. 2005). Daí por diante, Schatten subverteu sua posição: já não se apresentava como alguém próximo, mas, ao contrário, anunciava-se como alguém estranho ao que se passava no laboratório.

Com a deserção de Schatten, um nome de peso na rede de sustentação de Hwang, a fuga de aliados se acelerou. Roh, cientista sul-coreano e também coautor, lançou mais suspeição sobre a pesquisa ao afirmar ter havido falsificação de dados em pelo menos nove 
das 11 colônias de células-tronco e que o artigo estava sendo revisto (Coreano falsificou dados..., 15 dez. 2005; Colaborador diz..., 21 dez. 2005). Aqui também cabem algumas perguntas. Ele sabia da falsificação? Como veio a saber? Qual era seu papel, como autor? Segundo Roh, o próprio Hwang lhe havia dito que inventara parte dos resultados. Alguns membros da equipe negaram tais declarações, sem angariar muita confiança. Em seguida, outro pesquisador veio a público para afirmar que fora pressionado a fraudar. O diretor do hospital MIzMedi, parceiro do laboratório, que antes assumira a responsabilidade pela compra de óvulos, agora se juntava ao coro dos acusadores. Até então, exceto a publicação anônima que trazia argumentos técnicos, tudo o mais que dizia respeito ao descrédito de Hwang se sustentava em depoimentos de colaboradores ou ex-colaboradores. Isso chama mais uma vez a atenção para tensões e disputas existentes entre uma equipe: Hwang já não é um cientista-empresário bem-sucedido, não fala mais em uníssono com seus companheiros ou em nome deles.

Por fim, a comissão da UNS confirmou a fraude: as imagens haviam sido duplicadas nos artigos; as linhagens de células-tronco foram derivadas de embriões congelados, existentes no Hospital MIzMed; não havia evidência de que clone algum fora produzido; os testes de DNA foram forjados; e dinheiro fora desviado. O governo coreano revogou o título de Cientista Supremo concedido a Hwang, bloqueou os financiamentos e iniciou uma investigação sobre a malversação de verbas. A história ganhou, então, contornos policiais, com apreensão de computadores, interrogatórios de cientistas, buscas de indícios de uso privado do dinheiro para pesquisa etc. (Autoridades sul-coreanas..., 19 dez. 2005)

Depois de divulgado o relatório, Hwang fez uma aparição pública se desculpando e assumindo a responsabilidade pela fraude. Afirmou que "ficou cego pelo trabalho". Insistia, porém, que possuía tecnologia para clonagem humana, mas que fora enganado e que as linhagens foram contaminadas propositadamente por fungos. Pedia mais tempo e óvulos para continuar os experimentos e produzir as células-tronco sob medida (já se sabia, àquela altura, que, além da irregularidade na obtenção de óvulos, a quantidade usada fora muito superior à anunciada) (Clonagem..., 21 dez. 2005). Se ele afirmava possuir a tecnologia, como se explica que não tenha produzido os embriões clonados? Hwang dizia ter sido vítima de uma conspiração de cientistas do hospital que produziu os óvulos e acusava pessoas da equipe de terem trapaceado com ele, trocando células.

Isso nos alerta para outro aspecto da rede que, na divulgação dos conteúdos da ciência, não costuma ser mencionado: o modo de organização do trabalho no laboratório. $\mathrm{O}$ suposto é a existência de uma equipe coesa, integrada, e em situações normais o único a aparecer é o seu porta-voz. A história de Hwang, de início, não foi diferente: ele era o único e legítimo porta-voz do laboratório. Quando começaram as denúncias, por iniciativa de membros da equipe, outras vozes foram ouvidas. Confirmada a fraude, outra questão se coloca: como tantos pesquisadores puderam cooperar, talvez inadvertidamente, com ela? Cientistas que haviam visitado o laboratório se mostraram impressionados com aquilo que, aparentemente, permitira a frade: a divisão de tarefas altamente compartimentada e organizada. Era bastante possível, portanto, que um cientista não soubesse o que seu colega fazia (Último segundo..., 25 dez. 2005). Essa é uma das características da big science: o laboratório se amplia e cada pesquisador se apoia, em alguma medida, no trabalho 
realizado por outros, com quem não possui necessariamente relação direta e de confiança (Hackett, 2005; Mirowski, Horn, 2005). Em tal contexto, em que não há relações pessoais estabilizadas e baseadas na crença, na probidade ou mesmo na competência do outro, o que une os membros do laboratório?

Segundo, Knorr-Cetina (1999), um dos aspectos característicos da organização social do laboratório de biologia é sua natureza dual. De um lado, ele é composto de unidades individualizadas, voltadas para pesquisas próprias, pois cada cientista possui o seu projeto individual. De outro, opera como uma entidade única, centrada na figura do líder, que é na maior parte das vezes seu único elemento de integração. Além disso, o líder possui o "monopólio da interação com o campo" (Knorr-Cetina, 1999, p.223), pois é ele quem seleciona as informações sobre o laboratório que vão a público e, inversamente, que relações exteriores interessam ao laboratório (Knorr-Cetina, 1999; Teixeira, 1997). Muitos conflitos que surgem nesse domínio decorrem das ações do líder, que podem ser favoráveis ao laboratório, mas não necessariamente beneficiam todos os afetados por essas ações.

Outra fonte potencial de tensão é a competição entre diferentes pesquisadores pela atenção e reconhecimento do líder. Por fim, como apenas o líder aparece publicamente, o trabalho realizado no laboratório pelos pesquisadores é, em grande medida, invisível e considerado acessório e pouco relevante (Teixeira, 1997). Para Knorr-Cetina (1999, p.234), ao fim e ao cabo, aquilo que "une o laboratório é o mesmo que o divide - cria tensões, conflitos resistências e sentimentos de exploração".

Assim, podemos dizer que aquilo que favoreceu a fraude - a forma de organização e divisão do trabalho no laboratório - provavelmente foi também responsável por produzir as tensões que fizeram com que a fraude viesse à tona. Mas o que levou Hwang a fraudar? - esta foi a pergunta de jornalistas a vários cientistas (Ambição de publicar..., 29 dez. 2005). Para alguns, o pesquisador fora pressionado para mostrar avanços com relação à pesquisa de 2004, e com a publicação de 2005 obteve financiamento para a criação do banco mundial de células-tronco (Cientista sul-coreano se demite..., 23 dez. 2005). Uma cientista brasileira respondeu que certamente ele estava próximo de obter o resultado esperado e quis divulgar a notícia prontamente por dois motivos: pressão quanto ao prazo de entrega de relatório, fundamental para manter seu financiamento, e desejo de chegar em primeiro lugar, pois a ciência é empreendimento altamente competitivo. A questão é que os motivos que levaram Hwang à fraude - prazos, pressões, disputa para ser o primeiro - movem a prática da maioria dos cientistas, sobretudo aqueles que trabalham em áreas mais competitivas. Cientistas estão submetidos às mesmas pressões de prazos e financiamentos, mas não fraudam, embora um percentual considerável tenha admitido, em pesquisa publicada na Science, ter modificado suas metodologias para atender à demanda de financiadores, e um número menor deles confessou ter manipulado dados (Ambição de publicar..., 29 dez. 2005).

Alguns cientistas, preocupados com os efeitos do escândalo sobre a imagem da ciência, solicitaram à imprensa que se afastasse do caso. Outros se mostraram apreensivos com relação ao modo como a história poderia ser utilizada por grupos contrários à pesquisa com embriões, para fortalecer sua posição. Tal receio aponta um aspecto importante da relação entre ciência e jornalismo: não raro, a divulgação de descobertas é feita com o 
intuito de mobilizar aliados em defesa de pesquisas, em circunstâncias em que ocorrem disputa ética, contenda política em torno da legislação, ou luta para obtenção de financiamento. Tal fato é admitido explicitamente em uma matéria que traz um novo avanço nas pesquisas sobre células-tronco (a produção de um composto para cultivo de célulastronco que não utiliza células animais, portanto elimina fontes usuais de contaminação das linhagens). Diz o artigo que uma notícia favorável é importante para os estudos sobre células-tronco, pois a área passa por um momento delicado, decorrente da desconfiança gerada pela fraude de Hwang e da ameaça de restrição de verbas nos EUA (Descoberto meio de manter..., 16 fev. 2006). O jornalismo, ao priorizar notícias sobre achados promissores da ciência, é aliado importante de pesquisadores e laboratórios, e os ajuda na manutenção e no recrutamento de outras alianças e na obtenção de recursos.

A matéria mencionada remete também a outro aspecto que, embora já apontado, ainda não recebeu elaboração apropriada. Trata-se da importância conferida, na teoria do ator-rede, aos atores não humanos recrutados na construção da ciência. No artigo em questão, o aliado seria o composto para cultivo de células-tronco, mas na história de Hwang outros atores não humanos têm mais peso. Primeiro foram os óvulos - sempre aquém de suas necessidades; usados em quantidade maior do que anunciado; obtidos por meios não éticos; depois, a alegação, por parte do cientista, da perda de linhagens de células em virtude de ataque por fungos (as células clonadas não sobreviveram; ele não foi bemsucedido ao tentar cultivá-las). Poderíamos citar outros desses elementos atuando na trama. Se eles atuam, podem ser considerados atores? Para a teoria do ator-rede a resposta é sim, pois os agentes não humanos são atores de pleno direito. É claro que, para sustentar essa concepção, é preciso redefinir a agência, pois ela já não é pensada em termos de intencionalidade ou capacidade de atribuição de significados. Para saber sobre qualquer agente, segundo Latour (2005), as perguntas a fazer são: ele faz alguma diferença no curso de ação de algum outro agente? Há algum rastro que permita a alguém detectar essa diferença? Se a resposta for sim, teremos um ator, quer seja humano ou não humano. Isso não significa que Latour atribui intencionalidade aos não humanos, nem que ele destitui os humanos de intencionalidade ou capacidade de atribuição de significado. O que ele propõe é uma simetria analítica entre humanos e não humanos, ao enfatizar as mediações e diferenças produzidas pela ação de um ator na ação de outros atores.

Para a teoria do ator-rede não se pode pensar em termos de meros intermediários: "Os não humanos, sob a forma de equipamentos, soluções e instrumentos variados de inscrição, permitem a produção de novas situações, participam da produção de problemas, bem como da produção de novas possibilidades de lidar com eles" (Teixeira, 2005, p.12). No caso de Hwang a denúncia começou justamente em torno do processo de obtenção de óvulos, que de início eram meros figurantes na história e a partir das denúncias tornaram-se protagonistas. Passam a ser percebidos, problematizados; deixam de ser intermediários que transmitem sem modificar aquilo que é recebido e se tornam mediadores, agentes que fazem diferença em um curso de ação. Por sua vez, as supostas linhagens de células-tronco de embriões humanos clonados têm também papel destacado. Começaram, na história, como fato e acabaram como peça de ficção, pois Hwang não conseguiu produzi-las e cultivá-las. 
A agência dos não humanos se evidencia ainda na imprevisibilidade dos resultados das pesquisas científicas, a despeito do ordenamento prévio dos experimentos a partir de princípios e conhecimentos assentados (Knorr-Cetina, 1983, 1999). A possibilidade de erros e fracassos é imponderável. Por isso qualquer processo de construção de uma ordem, sustentada por elementos tão heterogêneos quanto linhagens de células, textos, imagens e técnicos, será sempre bastante precário. Assim se deu com Hwang. Ele conseguiu mobilizar uma série de aliados durante certo tempo - imprensa, colaboradores internacionais, políticos etc. -, mas não foi tão bem-sucedido assim com as CTEs. Os embriões não sobreviveram, não lhe deram a consagração esperada, e ele saiu da história não como o primeiro cientista a clonar embriões humanos, mas como um insidioso e farsante.

\section{Considerações finais}

As células-tronco embrionárias eram e são ainda descritas, nas publicações para leigos, como objetos de pesquisa com propriedades científicas e técnicas cujo suporte são certos fatos observáveis e concretos que apontam para uma realidade ainda não existente, mas que parece bem próxima: o tratamento para uma série de doenças incuráveis. Nessa perspectiva, nosso corpo e suas partes, instrumentos e seus usos, equipes de cientistas e laboratórios são tomados como realidades estáveis. Esquecemos a precariedade de suas existências, as contingências a que são submetidos, e tratamos como fenômenos simples e unitários aquilo que se apoia em uma rede extremamente complexa de ações, habilidades e utensílios, ou seja, simplificamos a ciência e seus objetos. No entanto, não se trata aqui de reafirmar a existência do que usualmente não transparece na divulgação de ciência, pois isso os estudos sociais em ciência e tecnologia, a antropologia e a sociologia da ciência já mostraram sobejamente. Também não pretendemos encerrar qualquer discussão, seja ela sobre a ocorrência de fraudes e as suas causas, ou sobre o jornalismo científico e o que determina as suas escolhas narrativas.

Em vez de pôr um ponto final em uma ou outra questão, preferimos deixar plantadas duas interrogações, uma que diz respeito à teoria social e outra, à divulgação de ciência. Para tanto, recapitulamos brevemente a história de Hwang tal como ela apareceu na imprensa. Os relatos começam com poucos atores e um fato estabelecido e simplificado: o cientista havia conseguido produzir linhagens de células-tronco a partir de embriões humanos clonados. Aos poucos, o que era tido como um dado perde a consistência, ao mesmo tempo que as complexas redes que constituem a ciência começam a ganhar visibilidade. Surgem os entrecruzamentos de diversas entidades heterogêneas: o governo coreano e seus funcionários; empresas de biotecnologia; canais de tevê; fundos para pesquisa; óvulos; linhagens de células e fungos; revistas científicas; imagens de células; esquemas de colaboração entre instituições, entre outras. E emergem não só as associações entre essas diferentes entidades, como também as tensões existentes entre elas e as dificuldades crescentes e incontornáveis de manter reunidos harmonicamente todos os componentes. Em geral, o jornalismo científico atua como um elemento que contribui para sustentar a 'realidade' dos fatos produzidos em laboratório, mas no caso de Hwang - após as denúncias - a mídia desfez essa aparente concretude e mostrou a precariedade da construção daqueles 'fatos'. 
No relato da fraude, de como e por que ela aconteceu, agentes e agências se multiplicam, aproximando mais o leitor do que é o mundo real em que são produzidos os fatos científicos.

Ao nos aproximarmos da experiência do fazer científico, uma das questões mais instigantes - mas também bastante polêmica - diz respeito ao lugar atribuído aos não humanos. Eles já não são tratados como componentes neutros do mundo social, que simplesmente espelham ou projetam relações sociais que lhes são independentes; são atores de pleno direito, não no sentido de que possuem intencionalidade ou atribuem significados, mas sim no sentido de que fazem diferença. Por conseguinte, a grande contribuição dos estudos sobre ciência e tecnologia para as ciências sociais não foi apenas a ampliação do campo de objetos abertos à investigação sociológica, mas sobretudo a abertura de uma perspectiva que coloca questões radicais à teoria social e exigem a redefinição de termos como causalidade, agência e sociedade, ao reafirmar o significado e a relevância das coisas para a vida social. Incluir igualmente os não humanos no coletivo implica uma compreensão do social que não põe nem a estrutura nem a interação como origem e explicação, mas situa o ponto de partida no meio, pois considera mediação toda ação. Dito em outras palavras, entende que um evento não pode ser definido em termos de causas e consequências, mas de uma cadeia de transformações da qual fazem parte coisas que, assim como os humanos (embora de modo distinto), produzem diferença, nos interrogam, são recalcitrantes, mas ao mesmo tempo estabilizam, fazem durar relações sociais. O quanto e em que medida essas ideias serão incorporadas à teoria social ainda não sabemos, mas a questão está colocada e o desafio, posto.

Como já dissemos, a trama da ciência se tornou visível graças às várias infrações cometidas por Hwang. Ainda assim, é possível reconhecer nessa história, para além de motivações pessoais e interesses talvez ilícitos, que o cientista estava conectado ao mundo da ciência normal. Ele agenciava recursos, organizava trabalho e instrumentos, padecia de pressões e problemas que não são, de modo algum, alheios à prática de qualquer cientista. Isso dilui qualquer distinção entre Hwang e outros cientistas? Acreditamos que não. Dizer que os fatos da ciência são construídos e se sustentam em uma rede complexa e heterogênea não implica nenhuma crítica específica, seja ela política ou epistêmica, ao conhecimento científico, tampouco sugere que devemos tratar todos os cientistas como manipuladores e todos os fatos científicos como falsos. Do mesmo modo, não quer dizer que as denúncias de fraude não fazem sentido. Ao contrário, a revelação dos falseamentos cometidos por Hwang mostra que faltava solidez e articulação à construção que ele tentava exibir como firme e bem assentada.

Agora, passado o momento de divulgação da fraude, questões relativas ao fazer científico deixaram de interessar à mídia. O jornalismo deve tratar desses temas apenas em situações que envolvem desvios? Que interesse pode ter, para o leigo, a complexidade da trama científica? Parece-nos que deveria ser de muito interesse. Se há, na contemporaneidade, consenso em torno da ideia de que ciência e tecnologia têm importância crescente em nossas sociedades, não devemos, como argumenta Knorr-Cetina (1999), nos limitar a reconhecer seus impactos positivos ou negativos para a vida social. Se não interrogamos seus modos de operação, deixamos intacta a aura de distinção que parece cercá-la, e a reafirmação dessa diferença com relação às demais esferas sociais não favorece a ampliação da participação 
pública em ciência, algo que tem sido estimulado mais recentemente (Irwin, 2006). Mostrar a ciência como um empreendimento prenhe de incertezas e contingências pode, por sua vez, promover uma relação com a ciência que seja mais marcada pela prudência, pelo cuidado, pela atenção com suas descobertas e seus resultados e com os desafios éticos que ela nos coloca.

\section{NOTAS}

* Este artigo é resultado de pesquisa realizada com apoio da Fundação de Amparo à Pesquisa do Estado da Bahia (edital PPP 2006, TO 0076/2006) e do Conselho Nacional de Desenvolvimento Científico e Tecnológico (Edital Universal 2007, processo 472916/2007-6).

${ }^{1}$ Nesta e nas demais citações de textos publicados em outros idiomas, a tradução é livre.

\section{REFERÊNCIAS}

AMBIÇÃO DE PUBLICAR...

Ambição de publicar e de ganhar dinheiro pode levar cientistas a trapacear. Folha de S.Paulo, São Paulo. Disponível em: http://noticias.uol.com.br/ultnot/afp/2005/12/ 29/ult1806u3029.jhtm. Acesso em: 18 jan. 2006. 29 dez. 2005.

AMERICANO VÊ PROBLEMA...

Americano vê problema na obtenção de óvulos para pesquisa, que teriam vindo de subordinada de cientista asiático. Folha de S.Paulo, São Paulo. Disponível em: http://www1.folha.uol.com.br/fsp/ciencia/ fe1411200501.htm. Acesso em: 18 dez. 2005. 14 nov. 2005.

ANIMAL AJUDARÁ ESTUDO...

Animal ajudará estudo genético de doenças. Folha de S.Paulo, São Paulo. Disponível em: http://www1.folha.uol.com.br/fsp/ciencia/ fe0408200502.htm. Acesso em: 18 dez. 2005. 4 ago. 2005.

AUTORIDADES SUL-COREANAS...

Autoridades sul-coreanas fecham laboratório do professor Hwang. O Estado de S.Paulo, São Paulo. 19 dez. 2005.

BAINS, William.

Fraud and scandal in biotech. Nature Biotechnology, New York, v.24, n.7, p.745-747. Disponível em: http://www.nature.com/nbt/ journal/v24/n7/full/nbt0706-745.html Acesso em: 10 out. 2008. 2006.

BENÍTEZ-BRIBIESCA, Luis; MODIANOESQUENAZI, Marcos.

Ethics of scientific publication after the human stem cell scandal, Archives of Medical Research, México D.F., v.37, n.4, p.423-424. Dsiponível em: http://www.arcmedres.com/home. Acesso em: 20 jan. 2009. 2006.

BENOS, Dale J et al.

The ups and downs of peer review. Advances in Physiology Education, Bethesda, v.31, p.145-152. 2007.

BOURDIEU, Pierre.

O campo científico. In: Ortiz, Renato (Ed.).

Pierre Bourdieu: sociologia. São Paulo: Ática. 1994.

CÉLULAS DE DECEPÇÃO...

Células de decepção em massa. Folha de S.Paulo, São Paulo. Disponível em: http://www1.folha. uol.com.br/fsp/ciencia/fe2412200503.htm. Acesso em: 11 jan. 2006. 24 dez. 2005.

\section{CIENTISTA COREANO APONTA ERRO...}

Cientista coreano aponta erro em edição de pesquisa. Folha de S.Paulo, São Paulo.

Disponível em: http://www1.folha.uol.com.br/ folha/ciencia/ult306u14028.shtml Acesso em: 16 dez. 2005. 7 dez. 2005.

CIENTISTA SUL-COREANO SE DEMITE...

Cientista sul-coreano se demite após fabricação de resultados de clonagem. O Estado de S.Paulo, São Paulo. 23 dez. 2005.

CIENTISTAS SUL-COREANOS CLONAM... Cientistas sul-coreanos clonam pela primeira vez um cachorro. Folha de S.Paulo, São Paulo. Disponível em: http://www1.folha.uol.com.br/ folha/bbc/ult272u45125.shtml. Acesso em: 19 dez. 2005. 3 ago. 2005.

\section{CLONAGEM...}

Clonagem: coreano usou mais de 900 óvulos, afirma ex-colega. Folha de S.Paulo, São Paulo. Disponível em: http://www1.folha.uol.com.br/ fsp/ciencia/fe2112200502.htm. Acesso em: 10 jan. 2006. 21 dez. 2005. 
COLABORADOR DIZ...

Colaborador diz que cientista sul-coreano adulterou resultados de pesquisa. Folha de S.Paulo, São Paulo. Disponível em: http:// www1.folha.uol.com.br/fsp/ciencia/

fe1612200501.htm. Acesso em: 16 dez. 2005. 15 dez. 2005.

COMO A SCIENCE PUBLICOU...

Como a 'Science' publicou uma fraude? O Estado de S.Paulo, São Paulo. Disponível em: http://www.estadao.com.br/arquivo/vidae/ 2006/not20060102p69047.htm. Acesso em: 15 jan. 2006.2 jan. 2006.

COREANO FALSIFICOU DADOS...

Coreano falsificou dados sobre células-tronco. Folha de S.Paulo, São Paulo. Disponível em: http://www1.folha.uol.com.br/folha/bbc/ ult272u49062.shtml. Acesso em: 16 dez. 2005. 15 dez. 2005.

COREANO QUE CRIOU CLONES...

Coreano que criou clones se encontra com arcebispo. Folha de S.Paulo, São Paulo. Disponível em: http://www1.folha.uol.com.br/ fsp/ciencia/fe1806200503.htm. Acesso em: 18 dez. 2005. 18 dez. 2005.

COREIA DO SUL CRIA BANCO...

Coreia do Sul cria banco mundial de célulastronco. O Estado de S.Paulo, São Paulo. 20 out. 2005.

COREIA DO SUL CRIA CÉLULAS-TRONCO... Coreia do Sul cria células-tronco a partir de clonagem humana. Folha de S.Paulo, São Paulo. Disponível em: http://www1.folha.uol.com.br/ folha/ciencia/ult306u13247.shtml. Acesso em: 19 dez. 2005. 9 maio 2005.

DASTON, Lorraine.

Scientific error and the ethos of belief. Social Research, New York, v.72, n.1, p.1-29.

Disponível em: http://www.socres.org/. Acesso em: 10 set. 2008. 2005.

DAVYT, Amilcar; VELHO, Léa.

A avaliação da ciência e a revisão por pares: passado e presente - como será o futuro?.

História, Ciências, Saúde - Manguinhos, Rio de Janeiro, v.7, n.1, p.93-116. 2000.

DELGADO, Mónica; VALLVERDÚ, Jordi. Valores en controversias: la investigación con células madre. Revista Iberoamericana de Ciencia, Tecnología y Sociedad, Buenos Aires, v.3, n.9. Disponível em: http://www.scielo.org.ar/ scielo.php?script=sci_arttext\&pid=S1850$00132007000200002 \& \operatorname{lng}=$ es\&nrm=iso\&tlng=es . Acesso em: 1 fev. 2009. 2007.

DESCOBERTO MEIO DE MANTER...

Descoberto meio de manter células-tronco embrionárias vivas. O Estado de S.Paulo, São
Paulo. Disponível em: http:// www.estadao.com.br/arquivo/vidae/2006/ not20060216p61758.htm. Acesso em: $17 \mathrm{fev}$. 2006. 16 fev. 2006.

EX-ADMIRADORES DE SUL-COREANO... Ex-admiradores de sul-coreano buscam explicações para a fraude. O Estado de S.Paulo, São Paulo. Disponível em: http:// www.estadao.com.br/arquivo/vidae/2006/ not20060112p69083.htm. Acesso em: 16 jan. 2006. 12 jan. 2006.

\section{FADIGA LEVA CIENTISTA...}

Fadiga leva cientista sul-coreano pioneiro na pesquisa de células-tronco para hospital. O Globo, Rio de Janeiro. 7 dez. 2005.

FOX, Cynthia.

Cell of cells: the global race to capture and control the stem cell. New York: Norton. 2008.

FOX, Mary Frank.

Fraud, ethics and the disciplinary context of science and scholarship. The American Sociologist, v.21, n.1, p.67-71. Disponível em: http://www.springerlink.com/content/19364784 ? sortorder $=$ asc $\&$ p_o $=60$. Acesso em: 25 dez 2008. 1990.

FRANZEN, Martina; RÖDDER, Simone; WEINGART, Peter.

Fraud: causes and culprits as perceived by science and the media - institutional changes, rather than individual motivations, encourage misconduct. EMBO Reports, Oxford, v.8, n.1, p.3-7. Disponível em: http://www.nature.com/ embor/index.html. Acesso em: 13 jan. 2008. 2007.

FRAUDE NA CLONAGEM...

Fraude na clonagem deixa cientistas na defensiva. Folha de S.Paulo, São Paulo. 25 dez. 2005.

GARFINKEL, Harold.

Studies in ethnomethodology. Englewood Cliffs: Prentice Hall. 1967.

GILBERT, Geoffrey Nigel; MULKAY, Michael. Accounting for error: how scientists construct their social world when they account for correct and incorrect belief. Sociology, v.16, n.2, p.165-183. Disponível em: http:// soc.sagepub.com/. Acesso em: 10 set. 2007. 1982.

GOTWEIS, Herbert; TRIENDL, Robert. South Korean policy failure and the Hwang débâcle. Nature Biotechnology, New York, v.24, n.2, p. 141-143. Disponível em: http:// www.nature.com/nbt/index.html. Acesso em: 10 out. 2008. 2006. 
GRUPO DE 30 PESQUISADORES...

Grupo de 30 pesquisadores diz duvidar que pioneiro tenha criado células geneticamente compatíveis com doentes. Folha de S.Paulo, São Paulo. Disponível em: http:// www1.folha.uol.com.br/fsp/ciencia/ fe1212200501.htm. Acesso em: 18 dez. 2005. 12 dez. 2005.

GRUPO PRODUZ LINHAGENS... Grupo produz linhagens de células-tronco clonadas: equipe faz primeira clonagem terapêutica produz embriões com células compatíveis com pacientes. O Estado de S.Paulo, São Paulo. 19 maio 2005

GRUPO QUE FEZ PRIMEIRA CÓPIA... Grupo que fez primeira cópia genética de ser humano dá primeiro passo para a aplicação terapêutica da técnica. Folha de S.Paulo,

São Paulo. Disponível em: http://www1.folha. uol.com.br/fsp/ciencia/fe2005200501.htm. Acesso em: 18 dez. 2005. 20 maio 2005.

HACKETT, Edward J.

Essential tensions: identity, control, and risk in research. Social Studies of Science, London, v.35, n.5, p.787-826. Disponível em: http:// sss.sagepub.com/. Acesso em: 10 out. 2008. 2005.

HOPWOOD, Nick.

Pictures of evolution and charges of fraud: Ernst Haeckel's embryological illustrations. Isis, Washington D.C., v.97, n.2, p.260-302.

Disponível em: http://www.journals. uchicago.edu/toc/isis/current?cookieSet=1. Acesso em: 22 jun. 2008. 2006.

HORST, Maja.

Cloning sensations: mass mediated articulation of social responses to controversial

biotechnology. Public Understanding of Science, Bristol, v.14, p.185-200. Disponível em: http:// pus.sagepub.com/. Acesso em: 15 out. 2005. 2005.

HWANG, Woo Suk et al.

Patient-specific embryonic stem cells derived from human SCNT Blastocysts. Science, v.308, p.1777-1783. Disponível em: http:// www.sciencemag.org/. Acesso em: 10 out. 2008. Artigo anulado. 2005.

HWANG, Woo Suk et al.

Evidence of a pluripotent human embryonic stem cell line derived from a cloned blastocyst. Science, v.303, n.5664, p.1669-1674. Disponível em: http://www.sciencemag.org/. Acesso em: 10 out. 2008. Artigo anulado. 2004.

IRWIN, Alan.

The politics of talk: coming to terms with de 'new' scientific governance. Social Studies of
Science, London, v.36, n.2, p.299-320.

Disponível em: http://sss.sagepub.com/. Acesso em: 22 mar. 2006. 2006.

KNORR-CETINA, Karin.

Epistemic cultures: how the sciences make knowledge. Cambridge: Harvard University Press. 1999.

\section{KNORR-CETINA, Karin.}

New developments in science studies: the ethnographic challenge. Canadian Journal of Sociology, Peterborough, v.8, n.2, p.153-177. Disponível em: http://ejournals.library. ualberta.ca/index.php/CJS/index. Acesso em: 17 set. 2007.1983.

KRUVAND, Marjorie; HWANG, Sungwook. A cross-cultural narrative analysis of the South Korean cloning. Science Communication, v.29, n.2, p.177-197. Disponível em: http:// scx.sagepub.com/. Acesso em: 10 out. 2008. 2007.

KUA, Eunice; REDEER, Michael; GROSSEL, Martha J.

Science in the news: a study of reporting genomics, Public Understanding of Science, Bristol, v.13, p.309-322. Disponível em: http:// pus.sagepub.com/. Acesso em: 15 out. 2005. 2004.

LATOUR, Bruno.

Reassembling the social: an introduction to cctor-network-theory. Oxford: Oxford University Press. 2005.

LATOUR, Bruno.

A ciência em ação: como seguir cientistas e engenheiros sociedade afora. São Paulo: Editora Unesp. 2000.

\section{LATOUR, Bruno.}

Vida de laboratório: a produção dos fatos científicos. Rio de Janeiro: Relume Dumará. 1999.

LAW, John.

Notas sobre a teoria do ator-rede: ordenamento, estratégia, e heterogeneidade. Trad., Fernando Manso. Disponível em: http://www.necso. ufrj.br. Acesso em: 17 de jun. 2005. 1992.

LAW, John.

O laboratório e suas redes. Trad., Ana Lúcia do Amaral Villasboas. Disponível em: http:// www.necso.ufrj.br. Acesso em: 17 de jun. 2005. 1989.

LEIBEL, Wayne.

When scientists are wrong: admitting inadvertent error in research. Journal of Business Ethics, v.8, n.10, p.601. Disponível em: http:// www.springer.com/sociology/applied+ethics/ journal/10551. Acesso em: 21 ago. 2007. 1991. 
LYNCH, Michael.

Protocols, practices, and the reproduction of technique in molecular biology. British Journal of Sociology, London, v.53, n.2, p.203-220.

Disponível em: http://www2.lse.ac.uk/BJS/

Home.aspx. Acesso em: 03 abr. 2007. 2002.

LYNCH, Michael.

Scientific practice and ordinary action:

ethnomethodology and social studies of science. Cambridge: Cambridge University Press. 1993.

LYNCH, Michael; WOOLGAR, Steve. Representational practice in science. Human Studies, v.11, p.99-116. Disponível em: http:// www.springer.com/philosophy/journal/10746. Acesso em: 31 jul. 2007. 1988.

LYTTON, Hugh.

'This is how it's always has been done': the treatment of academic misconduct in Canada. Canadian Journal of Sociology, Peterborough, v.21, n.2, p.223-235. Disponível em: http:// ejournals.library.ualberta.ca/index.php/CJS/ index. Acesso em: 10 out. 2008. 1996.

MALONE, Ruth E.; BOYD, Elizabeth; BERO, Lisa A.

Science in the news: journalist's construction of passive smoking as a social problem. Social Studies of Science, London, v.30, n.5, p.713-735, Disponível em: http://sss.sagepub.com/. Acesso em: 15 out. 2005. 2000.

MERTON, Robert K.

La sociología de la ciencia. Madrid: Alianza. 1985.

MIROWSKI, Philip; HORN, Robert Van.

The contract research organization and the commercialization of scientific research. Social Studies of Science, London, v.35, n.4, p.503-548. Disponível em: http://sss.sagepub.com/. Acesso em: 10 out. 2008. 2005.

MULKAY, Michael.

The embryo research debate. Cambridge: Cambridge University Press. 1997.

NERESINI, Frederico.

And the man descended from the sheep: the public debate on cloning in the Italian press. Public Understanding of Science, Bristol, v.9, p.359-382. Disponível em: http:// pus.sagepub.com/. Acesso em: 15 out. 2005. 2000.

PERFIL...

Perfil: veterinário é 'workaholic' e orgulhoso. Folha de S.Paulo, São Paulo. Disponível em: http://www1.folha.uol.com.br/fsp/ciencia/ fe2412200502.htm. Acesso em: 10 jan. 2006. 24 dez. 2005.
PETERSEN, Alan.

Replicating our bodies, losing ourselves: news media portayls of human cloning in the wake of Dolly. Body and Society, Nottingham, v.8, n.4, p.71-90. Disponível em: http://bod.sagepub. com/. Acesso em: 27 dez. 2005. 2002.

PICKERING, Andrew.

The mangle of practiceI: time, agency \& science. Chicago: The University of Chicago Press. 1995.

PIONEIRO DA CLONAGEM ADMITE...

Pioneiro da clonagem admite ato antiético. Folha de S.Paulo, São Paulo. Disponível em: http://www1.folha.uol.com.br/folha/bbc/ ult272u48380.shtml. Acesso em: 10 dez. 2005. 24 nov. 2005.

PIONEIRO NA CLONAGEM ACUSADO... Pioneiro na clonagem acusado de fraude está sob investigação. O Estado de S.Paulo, São Paulo. 16 dez. 2005.

PRIEST, Susanna Höring.

Clonning: a study in news production. Public Understand of Science, Bristol, v.10, p.59-69.

Disponível em: http://pus.sagepub.com/. Acesso em: 12 ago. 2006. 2001.

\section{PROMESSA NA MEDICINA...}

Promessa na medicina: experimento inédito abre perspectiva de transplantes celulares sem risco de rejeição. Folha de S.Paulo, São Paulo. Disponível em: http://www1.folha.uol.com.br/ fsp/ciencia/fe1302200401.htm. Acesso em: 18 dez. 2005. 13 fev. 2004.

SCHACHMAN, Howard K. From. 'Publish or perish' to 'patent and prosper'. Journal of Biological Chemistry, Baltimore, v.281, n. 11, p.6889-6903. Disponível em: http:// www.jbc.org/. Acesso em: 16 abr. 2010. 2006.

SHAPIRO, David W.; WENGER, Neil S.; SHAPIRO, Martin F.

The contributions of authors to multiauthored Biomedical research papers. The Journal of American Medical Association, Chicago, v.271, n.6, p.438-442. Disponível em: http:// jama.ama-assn.org/. Acesso em: 25 set. 2008. 1994.

SHORETT, Peter; RABINOW, Paul.

The changing norms of the life sciences. Nature Biotechnology, New York, v.21, p.123-125.

Disponível em: http://www.nature.com/nbt/ index.html. Acesso em: 19 set. 2008. 2003.

STENGERS, Isabelle.

A invenção das ciências modernas. São Paulo: Editora 34. 2002.

SUL-COREANAS PROMETEM DOAR... Sul-coreanas prometem doar óvulos para ajudar cientista. O Globo, Rio de Janeiro. 6 dez. 2005. 


\section{SUL-COREANO ADMITE..}

Sul-coreano admite compra de óvulos para pesquisa: colega de pioneiro das células-tronco teria pagado US $\$ 1,400$ para doadoras. Folha de S.Paulo, São Paulo. 21 nov. 2005.

\section{SUL-COREANOS PROPÕEM..}

Sul-coreanos propõem parceria das duas Coreias. Folha de S.Paulo, São Paulo. Disponível em: http://www1.folha.uol.com.br/fsp/ciencia/ fe2506200503.htm. Acesso em: 1 ago. 2005. 25 jun. 2005.

\section{TEIXEIRA, Márcia.}

Interações entre humanos e não humanos na produção de conhecimentos tecnocientíficos em saúde: limites teórico-metodológicos da pesquisa nos estudos sociais da ciência e tecnologia. Trabalho apresentado no 12. Congresso Brasileiro de Sociologia. Belo Horizonte. 2005.

TEIXEIRA, Márcia.

Análise do processo de trabalho em laboratórios de pesquisa em saúde: uma proposta de investigação. Cadernos de Saúde Pública, Rio de Janeiro, v.13, n.4, p.711-721. Disponível em: http://www.scielo.br/ scielo.php?pid=0102-311X\&script=sci_serial. Acesso em: 24 jun. 2008. 1997.
TRAWEEK, Sharon.

Beamtimes and Lifetimes - The World of High Energy Physicists. Cambridge: Harvard University Press, 1988.

TV COREANA ADMITE FALHA...

TV coreana admite falha de ética em reportagens. O Estado de S.Paulo, São Paulo. 5 nov. 2005.

TV SUL-COREANA DEVE QUESTIONAR... TV sul-coreana deve questionar pesquisa com células-tronco. O Globo, Rio de Janeiro. 2 dez. 2005.

\section{ÚLTIMO SEGUNDO..}

Último segundo: falsa clonagem põe ciência na defensiva. Disponível em: http://noticias.uol. com.br/midiaglobal/nytimes/2005/12/25/ ult574u6146.jhtm. Acesso em: 26 dez. 2005. 25 dez. 2005.

UNIVERSIDADE SUL-COREANA AVALIARÁ... Universidade sul-coreana avaliará pesquisas sobre células-tronco. O Globo, Rio de Janeiro. 20 dez. 2005.

VARA, Ana Maria.

Ciencia y mercado: balance del caso Hwang. Química Viva, Buenos Aires, v.5, n.3, p.15-33. Disponível em: http://www.quimicaviva. qb.fcen.uba.ar/index.html. Acesso em: 10 out. 2008. 2006. 